\title{
UNIVERSIDADE E ESCOLA COMO LÓCUS DA PROFISSIONALIZAÇÃO DO ENSINO E DO TEMPO ENTRE-DOIS NO ESTÁGIO SUPERVISIONADO ${ }^{1}$
}

\author{
Dijnane Vedovatto \\ Universidade Federal de São Carlos - UFSCar \\ Samuel de Souza Neto \\ Universidade Estadual Paulista “Julio de Mesquita Filho" - UNESP/Rio Claro
}

\begin{abstract}
Resumo
Este trabalho teve como objetivos identificar e analisar a inserção profissional (IP) do estágio supervisionado (ES) na Educação Física (EF) e nas Licenciaturas (LI) em escolas estaduais. Nessa pesquisa qualitativa apresenta-se os dados de duas pesquisas entrelaçadas, na qual a primeira etapa realizou um estudo de caso, enquanto a segunda etapa, em desenvolvimento, concentrou na realização de uma pesquisa colaborativa - intervenção. Na primeira, estudo de caso, fez-se um mapeamento da IP do ES de EF nas escolas estaduais do que era feito; porém, na segunda, em andamento, partiu-se para uma pesquisa colaborativa (intervenção) no ES da EF e das LI das escolas estaduais da Diretoria de Ensino. Participaram 62 pessoas do campo educacional. Na produção dos dados utilizou-se: entrevista narrativa, análise documental e análise de conteúdo. Observou-se na IP dos estagiários um divisor de águas na formação do professor, envolvendo: tensões, enfrentamentos distintos, aprendizagens intensas e desafios por ocasião do conhecimento da realidade. Este processo provocou a revisão do ES na rede estadual a partir da parceria, concretizando a formação no tempo entre-dois.
\end{abstract}

Palavras-chave: Formação Profissional; Educação Física; Licenciaturas.

\begin{abstract}
This work aimed to identify and analyze the professional insertion (IP) of the supervised internship (ES) in Physical Education (EF) and in Graduation (LI) in state schools. In this qualitative research, data from two interlaced surveys are presented, in which the first stage carried out a case study, while the second stage, under development, focused on conducting a collaborative research intervention. In the first, case study, a mapping of the IP of the ES of EF was made in state schools of what was done; however, in the second, in progress, a collaborative research (intervention) was carried out in the ES of the EF and of the LI of the state schools of the Directorate of Education. 62 people from the educational field participated. In the production of the data it was used: narrative interview, document analysis and content analysis. It was observed in the interns' IP a watershed in the teacher training, involving: tensions, different confrontations, intense learning and challenges when knowing the reality. This process provoked the revision of the ES in the state network from the partnership, concretizing the formation in the time between two.
\end{abstract}

Keywords: professional development; Physical Education; Teaching Licenses. 


\section{Introdução}

Este trabalho trata da inserção do estágio supervisionado (ES) da Educação Física em escolas estaduais, considerando os desafios e as possibilidades dessa prática docente no desenvolvimento profissional de professores (Libâneo; Pimenta, 1999). Na sequência da pesquisa com Educação Física amplia-se esta proposta para uma segunda pesquisa, em andamento, com a todas as Licenciaturas de formação de professores que estão inseridas em escolas estaduais, pensando na parceria entre universidade e escola como uma "política de formação".

Tardif e Raymond (2002) e Marcelo Garcia (1999) compreendem a inserção profissional como um divisor de águas na formação do professor, pois envolve tensões, enfrentamentos distintos, aprendizagens intensas e desafios por ocasião do conhecimento da realidade. Tratase de um período de constituição de uma identidade profissional, de conhecimento da cultura escolar e de isolamento na escola. Assim, muitos estudantes em situação de estágio e professores principiantes vivenciam as experiências da inserção profissional de forma isolada (Tardif, 2010), sem alguém que de fato os orientem ou os acolha e os acompanhe em seu desenvolvimento profissional.

No que diz respeito ao desenvolvimento profissional, Cochran-Smith (2012) assinala que é processual e se modifica ao longo do tempo, sendo influenciado por distintos aspectos do presente, vinculados à adequação na nova experiência ou anteriores à própria formação inicial, concernentes à etapa da socialização primária (família, escola). Dessa forma, este período se torna especial e extremamente relevante para a permanência ou não do estagiário e do professor principiante na escola (Marcelo Garcia, 1999).

Neste cenário, embora a literatura venha sublinhando a importância do ES e apontando para os seus limites, Azevedo (2009) reconhece que ele tem sido fundamental nos processos formativos dos futuros professores. Na visão da autora, o ES permite estabelecer relações entre os saberes produzidos na universidade e na escola, pois pressupõe "ações pedagógicas efetivadas em um ambiente institucional de trabalho, reconhecido por um sistema de ensino, que se concretiza na relação interinstitucional estabelecida entre um docente experiente e o estagiário com a mediação de um supervisor" (Azevedo, 2009, p.39). Kulcsar (1998, p.65) aponta que a inserção do estagiário no ambiente escolar permite inúmeros conhecimentos para a formação docente, pois o ES consiste em "assumir a sua função prática, revisada numa dimensão mais dinâmica, profissional, produtora, de troca de serviços e de possibilidades de abertura para mudanças".

Entre os limites apontados, Franco (2008, p.11) assinala que tem havido uma fragmentação do processo formativo, no qual há uma ideia de que é preciso primeiro se apropriar da teoria para depois aplicá-la na prática. Parece haver uma grande lacuna entre o que é aprendido nas escolas e nas instituições formadoras. Sarti (2009, p.135) chama a atenção para a questão de que as instituições de formação de professores "não costumam manter um trabalho articulado com as escolas de educação básica que recebem seus estagiários, apesar da existência de orientações legais a esse respeito"; assinalando que o mais comum é os estudantes das licenciaturas realizarem "o estágio de docência em escolas 
escolhidas em função de suas preferências individuais e que nelas efetuem as atividades de observação e/ou de regência a partir de orientações gerais oferecidas pela instituição formativa".

Isse e Molina Neto (2016), ao fazerem um levantamento - em Banco de Teses e Dissertações da CAPES (2008-2014) e em periódicos na área da Educação Física -, selecionaram duas teses, sete dissertações e 29 artigos sobre o assunto. Dessa análise, constataram como desafios a serem enfrentados: o restrito diálogo entre universidade e escola; o papel do professor colaborador e da escola básica como formadores; o acompanhamento restrito aos estagiários por parte de algumas instituições formadoras; a dicotomia entre teoria e prática e a centralidade de ações de teor utilitário (Isse; Molina Neto, 2016). Em outro estudo, Silva Junior e Oliveira (2018), ao analisarem periódicos da área (1996-2016), acrescentam, aos desafios arrolados, questões relativas ao trato didáticopedagógico; a formação; e a falta de pesquisa no campo da legislação.

No geral, a grande questão que emerge é, ainda, uma clara desarticulação entre as instituições formadoras, sendo necessária a criação de projetos de estágio visando uma integração entre universidade e escola, para que os estágios possam servir como condutores das atividades que serão desenvolvidas na escola, vinculadas aos projetos da escola e da universidade (Azevedo, 2009). Dessa forma, no campo do ES, passa-se a interrogar "o grau de interação existente entre as instituições formadoras e as instituições estagiadas, a capacidade de diálogo entre os saberes dessas duas instituições e entre os profissionais que nelas atuam" (Giglio, 2010, p. 380).

Nas Diretrizes Curriculares Nacionais para a Formação de Professores da Educação Básica, há a indicação de que o ES deve ser desenvolvido tendo como perspectiva a elaboração de um projeto de estágio, planejado conjuntamente entre a Universidade e a Escola (Brasil, 2001). Portanto, concebe-se o ES como um tempo de aprendizagem com um profissional em exercício no seu campo de atuação, apontando para um trabalho de parceria interinstitucional, pois ele deve "ser realizado em escola de educação básica, e respeitado o regime de colaboração entre os sistemas de ensino, (...) e ser avaliado conjuntamente pela escola formadora e a escola campo de estágio" (Brasil, 2002, p.1), realidade essa que foi referendada também na Resolução CNE/CP 2/2019 - Formação Inicial de Professores.

Embora haja essa indicação da necessidade de parceria, Gatti e Barreto (2009) reafirmam a falta de colaboração entre as instituições formadoras, pois os estágios têm se mostrado vagos e sem vinculação com os sistemas escolares. Oliveira e Santos (2018, p.19) apontam que a "pouca eficácia dos estágios na formação dos futuros professores e a ausência de acompanhamento profissional aos principiantes são alguns dos problemas destacados na literatura sobre formação de professores”. Da mesma forma, Gatti et al. (2019), ao falarem da articulação entre formação inicial e formação continuada, assinalam também que não há uma tradição de compromisso das instituições superiores de formação inicial no acompanhamento dos profissionais docentes que elas formam.

Assim, no campo do ES, assiste-se a desencontros marcados ao nível do discurso e das políticas de formação e a um progressivo avanço no processo formativo, envolvendo a universitarização e a disciplinarização (Brasil, 1996), em descompasso com a escola. De 
forma que se pode entrar na era da profissionalização (Valle, 2003), considerando o processo de universitarização da formação, ao mesmo tempo em que com a escola se pode estar na etapa pré-profissional (Hargreaves, 2000) ou vocacional (Tardif, 2013) no campo do ES, se este estiver enquadrado apenas na observação de professores e na aprendizagem por tentativa-erro. Porém, não se deve transferir essa responsabilização para a escola, mas, sim, para o sistema que tem engendrado as políticas públicas no campo da Educação em sua metáfora de ziguezague (Saviani, 2009), marcada por avanços e retrocessos.

Dentro desse contexto, a universidade pode ter proposições de ES no Projeto PolíticoPedagógico coerentes, mas, sem dar um tratamento adequado a essa prática de ensino, ela pode ficar na aprendizagem artesanal da docência (Souza Neto, Sarti, Benites, 2016; Vedovatto, Souza Neto, 2015b). Do mesmo modo que a escola pode receber o estagiário e encaminhá-lo para o professor da sala de aula, mas, sem que este o acolha como um "formador" (Brasil, 1999), o estudante pode não passar de observador da sala de aula ou ficar na condição de uma espécie de auxiliar desse professor. Portanto, o desafio a ser enfrentado ocorre também no âmbito das mentalidades, na superação de que o ensino é algo fácil de ser realizado, não superando o mito de que se aprende fazendo (Hargreaves, 2000), na forma de uma capacitação em serviço (Saviani, 2009).

Da mesma forma, não se pode deixar de destacar "o caráter político do estágio e da formação docente para denunciar os (...) elaborados discursos dos reformadores empresariais da educação" (Ribeiro; Araújo, 2017, p.1731), que estão introduzindo a estandardização de conteúdos e currículos escolares como parâmetro de qualidade da educação brasileira (Adrião et al., 2009).

Superar essa mentalidade, bem como algumas lacunas do próprio ES, são alguns dos desafios do século XXI, pois a educação se tornou mais complexa e a preparação do professor mais exigente no âmbito dos normativos legais.

A partir desse cenário, surgem algumas questões: Como ocorre a inserção dos estágios nas escolas? Como são estabelecidas as parcerias entre as instituições formadoras? Como os estagiários são orientados?

Em função desses questionamentos, esta pesquisa tem como problema de estudo: quais são os elementos da inserção profissional do ES em Educação Física (EF) e das Licenciaturas (LI) na escola? Objetivamente, este estudo busca identificar e analisar a inserção profissional do ES na escola, tendo como referência a docência como profissão.

Parte-se do pressuposto de que, na legislação brasileira, Universidade e Escola passam a ser consideradas como lugares de formação (Brasil, 2019), integrando os currículos de formação inicial com os currículos de formação escolar. Porém, a grande novidade na literatura é o reconhecimento de um tempo entre-dois (Nóvoa, 2019) ${ }^{1}$ que envolve este amplo espaço de formação. Nóvoa (2019, p. 200) compreende "esse tempo entre-dois, entre o fim da formação e o princípio da profissão", como um período em que se estabelece uma ponte entre a universidade e as escolas, em um processo progressivo de aquisição de uma "dimensão socioprofissional" (Sarti, 2020), bem como de cultivo de uma cultura profissional.

Dizer que a docência é uma profissão significa considerar a passagem de um ofício artesanal, em que se aplicam técnicas e regras, a uma profissão, em que cada um constrói 
suas estratégias, apoiando-se em conhecimentos racionais e desenvolvendo sua especialização de ação na própria situação profissional, assim como sua autonomia (Altet, 2001, p. 25).

Na delimitação dessa autonomia docente, Contreras (2002) defende a ideia de uma profissionalidade docente, no âmbito da docência como profissão, questionando a teoria dos traços, a concepção clássica da teoria das profissões de concepção anglófona. Como contraponto, propõe o exercício de uma profissionalidade docente, sendo formada por uma obrigação moral, no sentido de ser portadora de uma moralidade e uma afetividade; um compromisso com a comunidade, primeiro com os pares e depois com a sociedade; e a competência profissional, indo além do saber fazer, mas estando articulada com a obrigação moral e o compromisso com a comunidade.

Gatti (2010, p. 1356) afirma que "a profissionalização de professores implica a obtenção de um espaço autônomo, próprio à sua profissionalidade, com valor claramente reconhecido pela sociedade", bem como assinala que "não há consistência em uma profissionalização sem a constituição de uma base sólida de conhecimentos e formas de ação".

Neste processo, Oliveira (2013, grifos nossos) chama a atenção para a questão de que a formação se torna condição de profissionalização, bem como a existência de um sentimento de pertença a um grupo, o que implica na constituição de uma identidade docente e de uma cultura profissional (Souza Neto; Cyrino; Borges, 2019). Portanto, ganham relevo tanto a formação inicial como a formação continuada, como processos de desenvolvimento profissional, e de profissionalização. A partir dessa perspectiva, Gatti (2010, p. 356) sublinha que podemos sair "do improviso, da ideia do professor missionário, do professor quebragalho, do professor artesão, ou tutor, do professor meramente técnico", para adentrar a concepção de um profissional que tem condições de "confrontar-se com problemas complexos e variados, estando capacitado para construir soluções em sua ação, mobilizando seus recursos cognitivos e afetivos".

No entanto, Savoie (2009), ao falar da profissionalização na educação, afirma que não se pode ignorar o quadro conceitual mais amplo da sociologia das profissões, considerando: a prática de um ofício em tempo pleno; a existência de um estatuto legal de reconhecimento das qualificações dos seus membros, como uma formação específica; e o vínculo com associações profissionais. Neste contexto, o movimento da profissionalização do ensino (Holmes Group, 1986) ganhou relevo ao introduzir a ideia de profissão no campo da educação proveniente da cultura anglófona, advogando a emergência de um perfil profissional dos professores a partir da estruturação de sua carreira. Enfatiza-se a importância de uma formação inicial de alto nível centrada na escola e a formação continuada construída e acompanhada pelos próprios pares. Dessa compreensão, emergiram três objetivos centrais: melhorar o desempenho do sistema educativo; passar do ofício à profissão e construir uma base de conhecimento para ensinar.

No Brasil, a questão da profissionalização do ensino ganhou visibilidade com a LDBEN 9394/96, quando se assinalou para uma mudança de paradigma, ao introduzir a proposta de formação dos "profissionais da educação" (Brasil, 1996), em substituição ao paradigma da formação de "educadores" (Brasil, 1961). Abandona-se a ideia de Matérias Pedagógicas ${ }^{2}$ 
como núcleo estruturante que fundamentou a formação de professores (Brasil, 1969) ao longo do século XX, tendo como matriz o curso de Didática ${ }^{3}$ (Brasil, 1939), na forma de um 3+1 (três anos de Bacharelado e um ano do curso de Didática), também denominado de verniz pedagógico. Com a LDBEN 9394/1996, passa-se a defender uma Base de Conhecimentos que dê sustentação a essa formação e prática pedagógica (Brasil, 1996), cujos encaminhamentos apareceram nas diretrizes de formação de professores (Brasil, 2002, 2015) e, posteriormente, na própria Base Nacional Curricular - Formação centrada em competências especificas: conhecimento profissional, prática profissional, engajamento profissional (Brasil, 2019).

Porém, cabe registrar novamente que, nesse processo, as políticas docentes são marcadas pela descontinuidade das políticas educacionais de formação, oscilando de governo a governo, na forma de avanços e retrocessos, como foi registrado na metáfora do ziguezague (Saviani, 2008). Neste cenário de ziguezague, o nosso desafio aqui se constitui em focalizar a inserção do ES na Formação de Professores da Educação Básica, considerando o processo da profissionalização do ensino e a articulação entre Universidade e Escola.

\section{Procedimentos Metodológicos}

Nesta pesquisa qualitativa apresenta-se os dados de duas pesquisas entrelaçadas, na qual a primeira etapa realizou um estudo de caso, enquanto a segunda etapa, em desenvolvimento, concentrou na realização de uma pesquisa colaborativa - intervenção.

Com relação a primeira pesquisa, estudo de caso (Ludke; André, 2001), ela está circunscrita a um curso de licenciatura em Educação Física(Universidade Pública), ao qual um dos pesquisadores tem acesso, conhece a sua realidade, além de que este curso foi um dos primeiros a serem instalados no interior paulista. Portanto, o ES inserido no curso compõe uma instância particular, uma vez que é tratado como único, "uma representação singular da realidade que é multidimensional e historicamente situada" (Ludke; André, 2001, p.21).

No âmbito do estudo de caso foi utilizada a entrevista narrativa como técnica de pesquisa, entendida como uma forma de entrevista não estruturada, com características próprias (Alvez-Mazzotti; Gewandsznajder, 2001), envolvendo uma ou outra questão. A entrevista narrativa se constitui como uma forma de entrevista não estruturada, de profundidade e com características próprias, visando encorajar um determinado sujeito a contar a história sobre algum acontecimento importante de sua vida e do contexto social. A ideia é reconstruir acontecimentos sociais a partir da perspectiva dos informantes (Jovchelovitch; Bauer, 2002). As entrevistas ocorreram individualmente e, com o consentimento dos entrevistados, foram gravadas em áudio e transcritas integralmente para análise dos dados.

Assim sendo, no estudo de caso foram realizadas as entrevistas com sete participantes: a) três Diretores de escolas (Diretora R, Diretora M, Diretor G) que recebem estagiários do curso de Educação Física; b) a Coordenadora de Educação Física da Diretoria de Ensino (B); 
c) a Supervisora de Ensino da Diretoria de Ensino (A); d) um Professor Universitário (E); e) três Professores Colaboradores de Educação Física (S, P, N); e f) três Estagiários $(C, L, H)$ 12 participantes.

As entrevistas trouxeram dados significativos com relação as lacunas nos procedimentos de inserção dos estagiários nas escolas; revisão das responsabilidades de acolhimento e acompanhamento; reconhecimento da prática como processo de profissionalização; entre outros, fornecendo um tipo específico de mapeamento dos problemas. Estes problemas (organização dos estágios nas escolas, recepção do estagiário, papeis a serem executados pelo estagiário, professor orientador e professor supervisor, bem como o acompanhamento e a avaliação do estagiário) após a conclusão da pesquisa, ganharam vida na produção de um livro decorrente dessa investigação. Este livro- VEDOVATTO, D. e SOUZA NETO, S. Por uma revolução na prática de ensino: o estágio supervisionado. Curitiba: CRV, 2015b -foi levado e entregue a Dirigente da Diretoria de Ensino, desse contato e diálogo, que se travou com a Dirigente de Ensino e novos Supervisores, nasceu o convite para dar continuidade à pesquisa, tendo como meta inicial organizar o estágio na Diretoria de Ensino, começando pelos coordenadores pedagógicos.

Nesta segunda pesquisa opta-se pela metodologia do trabalho construtivo-colaborativo, pois ela se apoia na pesquisa construtivo-colaborativa (pesquisa colaborativa de intervenção) e passa a envolver todas as Licenciaturas de Formação de Professores sob a jurisdição de uma Diretoria de Ensino.

Cyrino (2016) aponta que ela tem dupla característica: de um lado desenvolve um trabalho colaborativo com a universidade e com a escola, ao mesmo tempo em que constrói, com os participantes, dispositivos formativos. Thiollent $(1994$, p. 14) assinala que o trabalho colaborativo surge a partir da perspectiva da pesquisa-ação, que é realizada em "estreita associação com uma ação ou com a resolução de um problema coletivo" e na qual "os pesquisadores e os participantes (...) estão envolvidos de modo cooperativo ou participativo"

Rinaldi, Dal-Forno e Reali $(2009$, p. 8) colocam que a pesquisa construtivo-colaborativa "não tem um delineamento configurado de forma detalhada e controlada a princípio, mas se constrói processualmente tendo como eixo o problema sob investigação". Enfim, todos os envolvidos "têm algo a aprender um com o outro, promovendo uma parceria entre pesquisador e formadores proporcionando aprendizagens mútuas” (p. 91).

Nesta nova etapa, esta pesquisa ${ }^{4}$ passa-se a trabalhar com os coordenadores pedagógicos (50 participantes - CP1... CP50), na condição de formadores que farão o primeiro acolhimento dos estagiários. Para este fim, estes coordenadores foram organizados em grupos de trabalho de cinco pessoas (GT1... GT10), na seguinte composição: GT1 (CP1... CP5); GT2 (CP6... CP10); GT3 (CP11... CP15); GT4 (CP16... CP20), GT5 (CP21... CP25); GT6 (CP26... CP30); GT7 (CP31... CP35); GT8 (CP36... CP40); GT9 (CP41... CP45) e GT10 (CP46... CP50). Dessa forma foram acrescentados dois dados desse trabalho (oficina pedagógica; encontro de estágio nas licenciaturas - documentos), em andamento, no conjunto dos outros dados vinculados a análise documental.

De acordo com Oliveira(2007), os documentos são registros escritos que proporcionam informações em prol da compreensão dos fatos e relações, pois se constituem em 
manifestações registradas de aspectos da vida social de determinado grupo. Assim sendo, a análise documental consiste em identificar, verificar e apreciar os documentos com uma finalidade específica, visando extrair da fonte original as informações contidas no documento, além da contextualização dos fatos em determinados momentos (MOREIRA, 2005).

Dessa forma, os elementos levantados nas descrições e textos foram apreciados tanto pela análise documental como pela análise de conteúdo. A análise de conteúdo (Franco, 2008) consiste em unidades de significado em uma estruturação e organização sistematizada para compreender o estudo em questão.

\section{A produção dos dados e a sua discussão}

A análise dos dados envolveu as transcrições das entrevistas da pesquisa principal, sendo complementados por dois dados preliminares de análise documental provenientes de uma segunda pesquisa em andamento. Dessa análise foram constituídos dois temas, a saber: (1) $o$ estágio supervisionado na visão de diretores, professores, supervisor de ensino e coordenador pedagógico: escola de ofício, educação prática (formação moral) e prática de ensino; e (2) pensar o estágio supervisionado como espaço e tempo entre-dois de formação na relação Universidade-Escola.

(1)O estágio supervisionado na visão de diretores, professores, supervisor de ensino e coordenador pedagógico: escola de ofício, educação prática (formação moral) e prática de ensino.

Os estágios supervisionados têm grande importância para a formação dos futuros professores, pois se configuram como um momento no qual há um contato direto com o campo profissional, bem como com os desafios da prática pedagógica. Assim, o que se busca descrever é como o seu desenvolvimento é observado, compreendido.

1a) O que acontece no estágio, na compreensão dos Diretores de Escola, Professores e da Supervisora de Ensino da Diretoria de Ensino, no que se refere a: entrada na escola, observação, acompanhamento, regência, contrapartida?

Ao falar sobre o estágio nas escolas, a Supervisora de Ensino da Diretoria de Ensino A aponta que ele funciona assim: "o estagiário vai diretamente na escola..., é poder do diretor aceitar ou não o estagiário”. Porém, na escola se pode adotar dois tipos de encaminhamento, um em que a coordenação pedagógica trata do assunto e outro em que o estagiário é encaminhado diretamente para o professor.

A gente encaminha para a coordenação; a coordenação vai pegar e encaminhar para o professor, (...) eles autorizam a fazer determinado estágio" (Diretor G). 
Então, quando alguém vem perguntar para mim de estágio, a primeira coisa que eu falo: então, você vai conversar com o professor, se o professor tiver..., tudo bem pra ele, por mim não tem problema" (Diretora $\mathrm{M}$ ).

Nas falas acima, podemos perceber que a Diretoria de Ensino (DE) se pauta em um acordo diretamente com a escola, pois se ancora na Lei 11788/2008, segundo a qual o estágio obrigatório só acontece se houver a assinatura de um contrato (Brasil, 2008), dando autonomia para que a DE aceite ou não o estagiário.

Os diretores, por sua vez, atribuem essa responsabilidade ao professor, que pode ou não aceitar o estagiário em suas aulas. A entrada do estagiário na escola corresponde à recepção de um "estrangeiro", de alguém que vem de fora. Neste contexto tácito em que se pensa que todos estão sabendo o que fazer, como fazer, por que fazer e quando fazer, a Diretora R questiona a etapa excessiva de observação na escola, ponderando que você não "aprende nada, se você não fizer...; essa história de você ficar só olhando, olhando, você não vai aprender nada".

Ela considera que a observação não contribui se não houver a prática de ensino. Nesta direção, ela se posiciona, ainda mais, ao colocar que "Eu abro estágio, mas na condição da ajuda, olhar por olhar não está fazendo estágio de nada, só está preenchendo papel” (Diretora R). A prática de ensino enfatizada na fala da diretora se constitui como um espaço original de aprendizagem e de formação dos futuros professores, bem como de produção de saberes e de práticas inovadoras de professores experientes (Tardif, 2010).

Outra questão que se torna também muito importante diz respeito ao acompanhamento do estagiário nas escolas, pois há a necessidade de que "o responsável esteja junto para que possa estar vendo qual é o desempenho?" (Diretor G). Este posicionamento também é acompanhado pela Diretora M: "E faz diferença o professor estar acompanhando, faz toda a diferença; então, a minha crítica é nesse sentido, sabe?”.

Os diretores enfatizam a necessidade de um acompanhamento mais próximo na escola, indicando a necessidade de uma orientação da universidade para os estagiários, pois identificam lacunas em relação a isso. A aproximação requerida pelos diretores está ligada a uma preocupação de articulação com a prática profissional dos futuros professores, considerando a orientação/acompanhamento uma tarefa exclusiva da Universidade.

(...) se o estagiário vem aqui, vem numa aula, vem na outra, só na observação, ele não entende esse contexto todo, então eu acho que é importante, e eu acho que tinha que ter mais tempo, né?, mais acompanhamento dos professores da faculdade, e ter esse envolvimento do pessoal. (...) (Professor P).

(...) mas no dia a dia realmente é complicado, então, isso é... a teoria e a prática, né? Pra ela ser colocada realmente no dia a dia, a gente percebe que é mais difícil, e aí os alunos lá que vêm lá da faculdade, eles percebem, nossa! Professor, mas é assim! Né? (Professor P). 
Eles pedem pra fazer estágio, tudo, eles começam a acompanhar, a ver as aulas, tudo, muitas das vezes eu os coloco pra ajudar, pra ir integrando junto com a gente aqui, inserir, né? Dentro do contexto, e eu pego bastante no pé em relação a isso, pra eles vim fazer, é dar regência, procura até dar mais do que cobram deles, que eu acho que eles têm que participar mais nessa situação. (Professor N).

Assim, além da preocupação com a articulação entre teoria e prática, a falta de conexão entre a Universidade e a Escola, requerida pelos entrevistados, também é ressaltada nas pesquisas, que indicam a necessidade de promover projetos de estágios em uma perspectiva profissional, bem articulados, em um movimento de integração entre Universidade e Escola (Sarti, 2009; Azevedo,2009). De modo que na escola "há situações problemáticas em um determinado contexto prático" (Imbernón, 2011, p.17) que o professor universitário precisa acompanhar, assim como o professor da escola (Brasil, 2008).

Porém, não basta só isso, há a necessidade de que haja também uma contrapartida da Universidade e dos estagiários:

Teve uma fase que a escola serviu muito de laboratório para universidade. O pessoal vinha, usufruía, estagiava, escrevia o que queria, e a gente não tinha acesso, não ficava sabendo de nada, que conclusão se chegou? Não tinha esse feedback, então, se for para não ter feedback, é melhor que nem faça, porque aí também você vai usar a escola como laboratório de experiência, e mais nada (Diretora R).

Esta questão é real, mas cabe registrar que há outros procedimentos adotados no campo do estágio; que, após o seu término, os estagiários apresentem, em reunião com os professores da escola, o que foi feito, ou entreguem para a Direção da escola um relatório (Souza Neto; Benites, 2013; Sarti, 2013).

No apontamento em questão, a Diretora $\mathrm{R}$ assume que no passado era raro se ter feedback, mas que no presente infere-se que haja, sendo enfatizado que, se não houver um comprometimento (Contreras, 2002) maior com a escola, é melhor que não se tenha estágio. Cabe ressaltar que, desde 2008, a Lei 11788 exige uma avaliação do estágio por parte da escola ou mesmo que o estágio possa ser interrompido por uma das partes se não estiver cumprindo com o plano de trabalho que a parte cedente e a parte concedente assinaram (Brasil, 2008).

Borges (2008) afirma que essa compreensão está associada, ainda, ao modelo curricular acadêmico de formação, por considerar a universidade como o grande polo da formação inicial. Tudo começa e termina na universidade, cabendo à escola um papel de coadjuvante. Porém, o que se busca é que as articulações entre a Universidade e a Escola possam ser melhor desenvolvidas na medida em que se viabiliza a dimensão experiencial, tendo como ponto de intersecção a lógica de que a prática dialoga com a formação (Franco, 2008).

Da mesma forma que se exige também uma atitude ética e moral em termos de comportamento na escola e fora dela, como foi apontado pela Diretora M: "existem 
estagiários éticos e estagiários nem tanto; então, aquela coisa, por exemplo, de sair de dentro da sala de aula do professor, falando alguma coisa" fora do ambiente escolar.

A questão da ética e da moral tem sido tratada na forma de uma deontologia no campo da Educação Física (Faria Junior; Corrêa; Bressane, 1982), bem como não deixam de ser trabalhadas experiências exitosas de estágios (Souza Neto; Benites, 2013). Porém, o choque de realidade do ensino (Huberman, 1995) causa apreensão em muitos estudantes, que, às vezes, não tomam os devidos cuidados nos seus comentários. Com certeza, este trabalho compete ao professor universitário que acompanha o estágio,aopreparar o estudante para chegar à escola e ter uma postura ética. Contreras (2002), ao defender a perspectiva de uma profissionalidade docente, coloca a obrigação moral como o primeiro aspecto em relação aos escolares, podendo-se incluir nessa relação a escola.

O Conselho Regional de Educação Física (CREF-4 - São Paulo) defende também uma conduta ética ao se trabalhar com as atividades físicas e motoras. O Guia de Normas e Procedimentos da Boa Prática da Educação Física e Esporte na Escola defende esta postura e um código de ética [São Paulo (CREF-4), 2013]. Mais recentemente, a Resolução CNE/CES 6, de 18 de dezembro de 2018, instituiu novas Diretrizes Curriculares Nacionais dos Cursos de Graduação em Educação Física, propondo, como novidade, o acompanhamento ético no processo de formação e intervenção profissional (Brasil, 2018). Todos esses apontamentos mostram que a observação da Diretora M procede, e muito, no campo do estágio.

\section{1b) O estágio segundo o discernimento do Diretor de Escola, da Supervisora de Ensino da Diretoria de Ensino, da Coordenadora Pedagógica da Educação Física na Diretoria de Ensino, do Professor Universitário e do Professor da Escola (Supervisor, Colaborador).}

Com relação ao papel da Universidade e da Escola, no âmbito do estágio supervisionado, há a compreensão, entre os entrevistados, de que a formação do professor é exclusividade da Universidade e que compete a eles abrir a porta da escola. Assim sendo, a Diretora M assinalou: "primeiro que eu acho que a gente abre as portas, eu sempre abri, porque eu acho que alguém tem que dar oportunidade".

A ideia de abrir as portas para o estágio parece ser o papel da escola na compreensão da diretora, no sentido de dar oportunidade, sendo também afirmado pelo Professor Colaborador S: "a parceria é nesse sentido de abrir a porta da escola, para a universidade vir aqui”. Porém, o professor da universidade alerta que:

(...) o estágio, ainda, é marginalizado nas escolas, em função daquele que ia lá, observava e julgava o professor e fazia relatório, falando besteira do professor e achavam que isso era o estágio. (Professor Universitário E).

Só que ele não fala o que tem feito para diminuir esta distância, antecipando-se aos desafios decorrentes do estágio. Da mesma forma que a Coordenadora da Área de Educação Física na Diretoria de Ensino assume que tem um grande desconhecimento sobre os estágios: 
"algumas pessoas me procuravam aqui na Diretoria de Ensino, mas eu não tenho um envolvimento com o estágio, (...) não participava dessa tramitação de estágio", porque na Diretoria de Ensino a sua função diz respeito a trabalhar com os campeonatos ou cursos de formação continuada. No entanto, este tipo de "indiferença" também é assumido pela Supervisora de Ensino da Diretoria de Ensino A, quando relata que a Diretoria de Ensino "antes não tinha, era solto" o seu envolvimento.

A esse respeito, Gatti (2010, p.1357) comenta que entramos no século XXI em uma condição de formação de professores nas áreas disciplinares em que, "mesmo com as orientações mais integradoras quanto à relação 'formação disciplinar/formação para a docência', na prática ainda se verifica a prevalência do modelo consagrado no início do século XX para essas licenciaturas". A autora enfatiza que a fragmentação formativa é clara, concluindo que é preciso integrar essa formação em currículos articulados e voltados ao objetivo precípuo (Gatti, 2010).

\section{1c) O estágio no âmbito Universidade-Diretoria de Ensino-Escola: a inserção do estagiário na escola, os questionamentos $e$ as tentativas de profissionalização.}

Embora se tenham retratado cenários de desafios e limitações no campo do estágio, há tentativas de profissionalização com a adoção de alguns procedimentos e medidas que apontam para perspectivas de uma melhor articulação, mas junto com a fragmentação pedagógica. Entre os procedimentos, o Diretor G solicita: ofício, plano de trabalho, carga horária, entre outros aspectos:

o estagiário deve trazer um ofício pedindo estágio; tem que ter um plano de trabalho; ele tem que fazer quantas horas? quais são os objetivos? o que que ele pretende aprender aqui? Para minimamente direcionar as pessoas.

A Diretora R enfatiza como deve ser feito o estágio na escola, pois entende que se deve ter um comprometimento:

(...) eu deixo, assim, muito claro no começo da nossa conversa o que tem que ser feito; como que tem que funcionar; como que é o estágio; se a pessoa achar que não dá, então procura outra escola que não tenha essa exigência e fica livre, entendeu? (Diretora R).

Entre outras iniciativas, a Supervisora de Ensino da Diretoria de Ensino A coloca que agora eles têm feito reunião com os professores das universidades e das escolas, com a finalidade de mostrar o que precisa ser feito no estágio.

Começamos a entrar em contato com as universidades, a gente chama o pessoal da universidade, daí eles vêm aqui e a gente fez já uma reunião do pessoal da universidade com o pessoal das escolas, diretores. 
Embora haja esta iniciativa, ela pondera que a chegada à escola ainda é caótica, concentrando-se os estudantes apenas em algumas escolas centrais ou tidas como boas escolas. Por sua vez, o Professor Universitário E assinala que o seu contato com a escola segue uma orientação, uma prescrição:

Meu contato com a escola é que o aluno vai para atuar com o professor. Fazer um plano de aula, ministrar essa aula, desenvolver essa aula, (...) junto com o professor, atuar como um futuro professor mesmo (...). Então, eu dou um plano de trabalho para as escolas, mostrando o que é o estágio; como funciona; o que a gente espera do estágio; quais são os deveres dos alunos; qual o dever do supervisor do aluno; o que a gente espera da escola como parceria e dos professores como parceria. (Professor Universitário E).

Esse tipo de direcionamento é confirmado pelo Diretor G: “O Professor da Universidade fala assim: quero que você vá lá e faça 3 horas só de observação, ou quero que você tenha de regência 10 horas..., ele vai ter que fazer".

(...) eu me lembro que o Professor (universitário) falava muito pra gente não se envolver com as crianças, e tentar ficar mais na observação, e a gente achava aquilo um tédio porque tinha que ficar sentado vendo as crianças, até inclusive a professora falava: Ah! Pode entrar, daí a gente falava não, o professor (universitário) falou que não e tal, (...) a gente conversava com a professora sempre depois das aulas pra ver, né? Falar de algum aluno, comentar de alguma atividade, mas não dei nenhuma aula além da regência, somente regência, a regência foi superlegal (Estagiária $\mathrm{C}$ ).

(...) porque no estágio, a maioria dos professores, a gente só vai lá acompanhar porque às vezes também você não tem o que fazer, o professor que eu tô agora a aula é dele é do jeito dele, então a gente não tem nada pra fazer a não ser acompanhar (Estagiária L).

(...) o do professor da universidade, ele bem dizer, avalia, né? Faz a avaliação, ele passa dicas ao longo desses encontros, igual o de hoje, dicas, tira dúvida, a gente expõe acontecimentos que a gente teve na escola, bem dizer é situações problemas, né? Aí eu contava o que acontecia lá, daí ele me aconselhava a fazer isso e aquilo, então era mais ele nessa preparação assim (Estagiário H).

Neste direcionamento, parece-nos que o elo mais fraco do estágio se torna o Professor Colaborador S, ao assinalar:

Por isso que eu falo isso para você, eu tenho a minha vida! Manhã, tarde e noite, e eu não vou me responsabilizar por isso. Eu abro espaço, converso, o que tiver, 
eu estou aqui à disposição, e nem todos abrem a escola para isso. Porque você não é obrigado. (Professor Colaborador S).

Na fala desse professor colaborador de Educação Física, há a afirmação de que a escola cede o espaço para o estagiário entrar na escola, observar e depois fazer uma intervenção, revelando o que compete a ele ao se referir ao estágio. Porém, o professor colaborador não se sente corresponsável pela formação do futuro professor. Benites (2012, p.27), ao falar do acompanhamento do estágio na Educação Física, enfatiza a questão do professor colaborador nos estágios, alertando para a necessidade de formação desses professores para receber os estagiários. Em sua análise, o "professor-colaborador está situado numa 'zona cinzenta', sem muita valorização", sem que haja uma proposta de formação voltada para a função de orientar os estagiários.

Embora haja esse cenário em que o professor colaborador considera que a formação do futuro professor seja atividade exclusiva da universidade, há por outro lado uma visão diferente, na qual o professor compreende que é corresponsável pelos estagiários na escola. Tal ideia podemos observar nas seguintes falas:

(...) se eu quiser realmente que eles vivenciem as coisas, eu vou propor essa vivência, eu vou trazer eles para a aula, né? Às vezes, alguns me pedem, né? Mas a maioria fica realmente só na observação. (Professor Colaborador P).

(...) por exemplo, os estagiários faziam uma regência, e parece que, naquele momento da regência, eles têm que resolver o problema do mundo, (...) então eu já negócio, já tô negociando com eles que essa regência que eles vão fazer não é mais uma aula, então, na regência deles, eles desenvolvem um tema, um bloco de no mínimo três aulas, né? O que não dá é as pessoas chegarem aqui, sentar e ficarem olhando eu dar aula, né? E... eu faço participarem, né? Eu não acredito no estágio de observação, eu acho que tem que pôr a mão na massa mesmo, né? (Professor Colaborador P).

O discurso do professor tem reflexos na estagiária quando ela descreve a sua percepção sobre o que ela considera como o seu melhor estágio:

Ele (professor colaborador) foi o melhor, ele estava sempre atento a tudo, (...) então ele usava umas estratégias muito boas, nossa! Ele tinha, assim, um feeling incrível, e eu achei muito bom o estágio que eu fiz lá. No fundamental 1 eu participei bastante das aulas, eu pedi para ele para dar algumas aulas, (...) eu montei o plano de aula antes, mostrei pra ele, daí ele falava:Não, vamos mudar aqui, vamos mudar ali, então junto comigo a gente ia montando a aula, e daí eu passava a aula sozinha com os alunos. (Estagiária C).

A estagiária revela a importância do professor colaborador durante o seu período de estágio, na direção de que é um profissional que contribuiu para a formação dela como futura 
professora. Ela enfatiza as aprendizagens que obteve com as ações promovidas pelo professor colaborador.

Hoje se reconhece a figura desse professor formador (Brasil, 1999), mas não há um lugar para ele na carreira docente. Então, o que se encontra é a "camaradagem" na parceria de trabalho entre o professor universitário e o professor de escola. Batista e Borges (2015) enfatizam também a complexidade do papel do professor colaborador nos estágios, que comporta a orientação do estagiário, além de contribuir para o desenvolvimento de uma postura reflexiva no futuro professor.

Na realidade, essa situação diz respeito a um grupo de dificuldades no qual, ainda, não se procedeu à incorporação de um "ponto de vista pedagógico" (Azanha, 2006), ou seja, uma perspectiva especificamente docente de formação, que possibilite aos agentes envolvidos o discernimento nas situações de ensino e a tomada de decisões. Sarti (2013) aponta para a necessidade de uma integração entre o campo de trabalho e a formação docente - na qual a escola é compreendida como o local de mobilização de saberes, e os professores experientes como formadores de seus pares.

(2) Pensar o estágio supervisionado como espaço e tempo entre-dois de formação na relação Universidade-Escola

Na parceria Universidade-Escola, elegemos o ES como espaço e tempo entre-dois de formação restrito à prática pedagógica, pois se caracteriza a prática como eixo de formação. Porém, Nóvoa (2017) propõe que a formação de professores seja pensada profissionalmente na direção de se buscar uma formação docente que seja feita de dentro para fora. Dentro desse contexto, a parceria entre Universidade e Escola se torna fundamental para que haja um intercâmbio de saberes, no qual haja uma relação de complementaridade entre as instituições formativas.

Nesse cenário, emergiu a primeira ação realizada na Diretoria de Ensino de São Carlos, ao reunir 50 coordenadores pedagógicos para fazerem uma oficina de formação de formadores. Altet (2016), ao analisar questões relativas à docência como profissão, afirma a necessidade de os formadores trabalharem em conjunto, para que haja a profissionalização do ofício e da profissão - de modo que o envolvimento de todos poderá alavancar mudanças na profissão. Assim sendo, a primeira mudança pretendida foi dar uma atenção especial à entrada do estudante na escola.

\subsection{O acolhimento do estagiário na escola}

Este tema surgiu em decorrência de se colocar como questionamento, após o diagnóstico realizado no estudo de caso, que, para haver um trabalho em conjunto, há a necessidade de se ter um objetivo comum para formar os professores como profissionais (Nóvoa, 2017). Portanto, pergunta-se: qual é o papel da escola na formação dos futuros professores? Quais 
são os papéis e funções atribuídos à escola e à universidade, quando nos remetemos ao ES? Quem deve ser formado nesse processo, para facilitar esse diálogo operativo?

Na reunião com a Diretoria de Ensino entendeu-se, inicialmente, que esta lógica passava por nós em termos de compreensão das dificuldades levantadas: falta de orientação do estagiário; desconhecimento da rede de ensino; a escola não saber direito o que fazer com o estagiário; o distanciamento do professor da universidade e da escola, entre outras. Porém, o aspecto decisivo estava no modo como o estudante chegava à escola. Assim, elegeu-se como mudança de mentalidade a recepção do estagiário na escola. Portanto, foi sugerido trabalharse primeiro com os coordenadores pedagógicos, pois tudo ligado ao ensino passava por eles, sendo os mediadores da escola com a realidade externa.

Nesse sentido, foram feitas duas oficinas formativas (OF1; OF2) com 50 coordenadores pedagógicos, realizadas pelos pesquisadores com a convocação e contribuição da Diretoria de Ensino, para se desenvolver uma reflexão sobre a entrada do estagiário na escola, bem como se estabeleceu como ele deveria ser recebido. Estas reuniões formativas tiveram como temas de reflexão "A parceria entre Diretoria de Ensino, Escola e Universidade na formação de professores: desafios, questionamentos e possibilidades para um trabalho em cooperação" (OF1); "A construção da identidade do professor na aprendizagem da docência: o papel da escola" (OF2). Os coordenadores trabalharam em grupos (GT1... GT10) após a exposição dos temas, apresentando sugestões e encaminhamentos, dentro de uma perspectiva de trabalho construtivo-colaborativa, tais como: a "construção da prática em conjunto (escola e universidade)" (GT5); "priorizar a prática" (GT8); "transformar a prática do estágio em experiência de fato" (GT2); "disseminar as boas práticas a serem protagonizadas" (GT4).

Eles afirmaram que a prática é um elemento essencial para o desenvolvimento do estágio nas escolas, enfatizando a necessidade de "superar pré-conceitos do estagiário para com a escola e vice-versa" (GT1); para um maior "contato do estagiário com o professor da escola para estabelecer combinados" (GT10); bem como para "fomentar e articular a construção de feedback (retornos) das ações realizadas pelos estagiários para a escola" (GT3), assim como para constituir "uma parceria, coletivamente estabelecida, a fim de direcionar as ações do estágio supervisionado" (GT6), com participação "efetiva do docente responsável pelo encaminhamento do estagiário da universidade para a escola" (GT9), o que "pode ocorrer com a universidade formando o professor para receber o estagiário" (GT7).

A partir dos apontamentos deste trabalho, emergiu a ideia de ACOLHIMENTO, no sentido de que o estagiário deveria ser integrado à escola, pois os processos de reflexão com o corpo de coordenadores pedagógicos sobre as suas próprias ações provocaram mudanças, levando-os a orientar os professores das escolas com relação aos novos dispositivos do ES, tendo como meta posterior levar os professores das escolas para essa formação. Nesse sentido, Tardif (2010) assinala que as profissões que lidam com o humano, na relação de seres humanos para seres humanos (dimensão relacional), desenvolvem um forte componente emocional, podendo suscitar uma teoria da interação social. Porém, mais do que isso, começou-se a desenvolver um "ponto de vista pedagógico" (Azanha, 2006) no âmbito do ES. 
Porém, a incorporação de um ponto de vista pedagógico nos levou a mais um passo nessa parceria, com a promoção de um encontro com todos os estagiários, tendo como perspectiva a proposta da prática como lócus de formação.

\subsection{Encontro de estágio supervisionado nas licenciaturas}

Nóvoa (2019, p. 206) relata um simbólico gesto com os estudantes de medicina, por ocasião de seu ingresso na universidade, na qual eles "são convidados a participar numa sessão onde os médicos do hospital, muitos deles igualmente professores na Faculdade de Medicina, lhes vestem um jaleco". Neste gesto, os estudantes passam a vestir "a pele da profissão", ao mesmo tempo em que os seus futuros colegas lhes dizem: "a vossa formação também é da nossa responsabilidade".

O sentimento de pertença ao lugar, ou à profissão, é exemplificado na situação acima, pois há, por parte dos médicos e professores, uma clareza sobre a corresponsabilidade na formação dos futuros médicos. Assim, é preciso construir uma parceria na qual haja clareza sobre as diferentes funções da escola e da universidade, considerando que a formação do futuro professor é uma tarefa que pode ser feita como um projeto comum.

Em outras margens, a exemplo da medicina, nasceu o "I Encontro de Estágio nas Licenciaturas" (2018), sendo realizado em uma escola pública centenária com anfiteatro, em um único dia, envolvendo mesa-redonda de abertura, exposição em pôsteres dos relatos de experiências de estágio - 70 trabalhos -, sala de conversa para a apresentação dessas experiências e duas mesas-redondas: uma com professores e estagiários de escola e a outra de encerramento, com a presença de 160 pessoas, sendo metade de estudantes, uma parte de coordenadores pedagógicos e o restante dividido entre diretores, professores universitários, supervisores e dirigentes ou autoridades de ensino. No ano seguinte, repete-se o evento, "II Encontro de Estágio nas Licenciaturas" (2019), nos mesmos moldes do primeiro, assim como o local, tendo a participação de 297 pessoas, 85 trabalhos, bem como a mesma proporção de participantes. Porém, nesse evento foi solicitada uma avaliação dos participantes, obtendose uma amostra de 20\% dos 297 participantes. Das avaliações realizadas, selecionamos um quadro representativo do que foi considerado como significativo pelos participantes de cada categoria. 
Quadro I - Encontro de Estágio nas Licenciaturas.

\begin{tabular}{|c|c|c|}
\hline \multirow{2}{*}{$\begin{array}{l}\text { EEL } \\
\text { Participantes }\end{array}$} & \multicolumn{2}{|r|}{2019} \\
\hline & Experiência & Parceria \\
\hline Estagiário & $\begin{array}{l}\text { É um espaço único (não conheço } \\
\text { outro tão eficiente) para a troca de } \\
\text { experiências/conhecimentos dos } \\
\text { diversos grupos de trabalhos. É } \\
\text { relevante politicamente para a } \\
\text { defesa da educação e do ensino. }\end{array}$ & $\begin{array}{l}\text { A parceria da Universidade com a Diretoria de } \\
\text { Ensino para mim foi de extrema importância } \\
\text { para a realização do meu estágio. Pois } \\
\text { proporciona oportunidades muito } \\
\text { significativas para a formação docente. }\end{array}$ \\
\hline $\begin{array}{l}\text { Professor da } \\
\text { Escola }\end{array}$ & $\begin{array}{l}\text { A troca de experiências entre os } \\
\text { participantes do encontro, pois } \\
\text { enriquece a prática docente tanto } \\
\text { dos que já estão em exercício quanto } \\
\text { dos que estão iniciando a carreira } \\
\text { docente. }\end{array}$ & $\begin{array}{l}\text { A possibilidade de ter no mesmo ambiente } \\
\text { estagiários e } \\
\text { colaboradores/atuantes. A apresentação de } \\
\text { trabalho em diferentes áreas da licenciatura. E } \\
\text { a ligação feita entre Universidade e Escola } \\
\text { através da Diretoria de Ensino. }\end{array}$ \\
\hline $\begin{array}{l}\text { Professor } \\
\text { Coordenador }\end{array}$ & $\begin{array}{l}\text { A socialização de boas práticas, pois } \\
\text { amplia a visão de como tornar o } \\
\text { estagiário mais parceiro nesse } \\
\text { processo de ensino/aprendizagem. }\end{array}$ & $\begin{array}{l}\text { É uma parceria que permite a todos realizar } \\
\text { um trabalho voltado à aprendizagem como um } \\
\text { todo (professor, aluno, estagiário, } \\
\text { universidade etc.). O estagiário chega mais } \\
\text { direcionado e o acolhimento permite que a } \\
\text { parceria aconteça de forma eficaz. }\end{array}$ \\
\hline $\begin{array}{l}\text { Professor } \\
\text { Supervisor }\end{array}$ & $\begin{array}{l}\text { O compartilhamento de } \\
\text { experiências nas rodas de conversa e } \\
\text { as atualizações sobre políticas } \\
\text { públicas na área de formação de } \\
\text { professores. }\end{array}$ & $\begin{array}{l}\text { Profissionalização dos papéis de cada um, } \\
\text { considerando-se cada um dos setores que } \\
\text { participa da parceria. }\end{array}$ \\
\hline
\end{tabular}

Fonte: Os autores.

No quadro apresentado, os destaques ficaram por conta do relato de experiências, envolvendo processos de socialização, troca e compartilhamento de experiências; e do reconhecimento do trabalho de parceria, envolvendo a ideia de integração, profissionalização dos papéis, formação docente.

No geral, o que se observou, a partir dos diferentes eixos de discussão, foi que o ES ocupa uma zona própria de articulação na relação entre Universidade e Escola, que pode ser caracterizada como um tempo e espaço entre-dois, inaugurando uma nova forma de se conceber esta formação, em alternância concomitante. Dessa forma, como fechamento dessa discussão, ficam alguns apontamentos que, se desenvolvidos de forma coerente, anunciam uma nova etapa do ES, assim como de uma pedagogia da formação para o ES que articule de forma integrada os diferentes itens:

a) Formação inicial - Os estágios na formação de professores foram considerados importantes, tendo a prática como o elemento preponderante no desenvolvimento das ações durante o período de ES. Mas é um trabalho que deve ser articulado a um projeto mais amplo de parceria Universidade-Escola. Ele deveria fazer parte do Projeto Curricular Pedagógico 
da Escola, assim como estar dentro do Projeto Curricular Pedagógico do Curso de Formação como um projeto.

b) Inserção do estagiário na escola - Ela tem um viés burocrático, pois as ações de parceria entre as instituições pesquisadas estão pautadas na abertura da escola para a realização dos estágios, mas não na preparação da escola e do professor de classe para acolherem e acompanharem o estagiário. Assim, o acolhimento concreto do estagiário na escola assume um papel relevante na efetivação de uma parceria mais sólida entre Universidade e Escola.

c) Acompanhamento do estagiário - Ficou evidente a falta de um acompanhamento mais objetivo dos estagiários nas escolas, não desconsiderando as experiências individuais exitosas, uma vez que a articulação do acompanhamento segue, ainda, concepções clássicas ou de natureza artesanal. Assim, formar para uma profissão vai além de deixar a cargo do professor a recepção e encaminhamento dos estagiários, sem que tenha havido qualquer formação ou orientação para isso.

d) Papel da Universidade, papel da Escola -As orientações legais prescrevem o que compete ao professor-orientador, ao professor-supervisor e ao estagiário (Brasil, 2008), mas não orientam no sentido da coformação institucional ou da formação do formador, concebendo, ainda, à Universidade a primazia dessa formação. Na contemporaneidade, aprender a trabalhar junto passa a ser uma necessidade na superação de obstáculos comuns. Neste contexto, o trabalho de parceria entre Universidade e Diretoria de Ensino é bem-vindo, pois se busca uma nova articulação, que passa pelo desenvolvimento de uma cultura profissional.

e) Emergência de uma cultura profissional - Embora haja um discurso enfático sobre a importância dos ES e da formação prática dos futuros professores, a inserção dos estagiários nas escolas abarca ações soltas, ficando, muitas vezes, a cargo do professor-supervisor a responsabilidade em receber e orientar os futuros professores. Não há qualquer tipo de formação formal ou algum tipo de promoção na carreira profissional para o professor de escola, pois a cultura profissional que fundamenta esse processo ainda é muito incipiente. Portanto, parece que oscilamos entre a idade da vocação e a idade do ofício (Tardif, 2010). Assim sendo, torna-se necessário produzir a vida do professor e a profissão docente (Nóvoa, 1992), bem como desenvolver a profissionalidade docente (Contreras, 2002), o que implica em se aprender a fazer a análise da prática profissional para se sair da tentativa-erro.

f) Análise da prática pedagógica - Com a valorização da formação prática (Brasil, 2002, 2015, 2018) e a assunção de uma base de conhecimentos (Brasil, 2002) que passa a fundamentar a prática, há a necessidade de que tanto o estagiário como o professor-supervisor aprendam a desenvolver a análise de prática, com vistas à profissionalização do ensino. Tratase, enfim, de ressignificar as nossas práticas (Souza Neto, Sarti, Benites, 2016).

g) Pensar a formação inicial como estrada de mão dupla-As ações descritas no corpo do texto evidenciaram fragilidades reveladas na parceria entre Universidade e Escola, que dificultam o cumprimento efetivo do que é defendido, pois não se desenvolveu uma cultura de colaboração em que as partes se colocam de acordo quanto aos papéis a serem assumidos e desenvolvidos (Vedovatto, Souza Neto, 2015a). Contribuem, para isso, a cultura disciplinar 
que ainda vigora na maior parte das universidades brasileiras; a falta de reconhecimento de que a escola se torna coformadora desse processo; de que o professor-supervisor é alguém que deveria ter a sua função reconhecida em termos de carreira profissional. Questão essa que desde o final do século XIX vinha sendo apontada na formação do professor de escola (Cyrino, 2016). Reconhecer que a formação de professores é um terreno que envolve uma via de mão dupla, um tempo entre-dois, é fundamental para a superação dos descompassos encontrados.

h) As novas políticas docentes - É preciso considerar que, nos últimos dez anos, alguns programas foram implementados, como é o caso do Programa Institucional de Bolsa de Iniciação à Docência (PIBID) e do Programa de Residência Pedagógica (PRP). Ambos os programas caminham no sentido da indução profissional financiada com um forte investimento público, o que é importante em termos de investimento na Educação, assim como se faz com a iniciação científica. O equívoco que se pode cometer é comparar os programas com o ES, no sentido de práticas concorrentes em relação ao ES, na dimensão de que eles têm o "poder" de resolver os descompassos que temos na realidade do ES. Se o ES está como está, há necessidade em cada curso de se rever o seu itinerário formativo, visando evitar às descontinuidades desse processo, apesar das experiências exitosas individualmente.

i) A docência como profissão - Conclui-se que, apesar das mudanças que vem sendo introduzidas nos últimos 30 anos no campo do magistério, estas não foram, ainda, suficientes para alterar quadros de desenvolvimento profissional docente (Tardif, 2010)nas licenciaturas. Mas que,não obstante, invalidam os esforços individuais ou coletivos que tem havido, como o trabalho que foi apresentado.

\section{Algumas considerações}

Este trabalho teve como problema de estudo: quais são os elementos da inserção profissional do ES em meio escolar, considerando o processo de profissionalização do ensino? No que se refere aos objetivos, buscou-se identificar e analisar esses elementos, assim como a profissionalização.

Neste cenário, as descobertas passam pelo mapeamento de uma rede de trabalho envolvendo: professor orientador, estagiário, diretor de escola, coordenador pedagógico, professor supervisor, supervisor de ensino, coordenação de educação física. Pode-se, ainda, colocar como outras pessoas envolvidas: os pesquisadores, a dirigente de ensino, a supervisora de ensino e duas coordenadoras de área. Porém, é uma rede que precisa de diálogo.

No grupo participante pesquisado, pode-se observar uma concepção tradicional de ES, em que os estudantes seguem uma perspectiva normativa de observações para, finalmente, realizarem uma regência, pois se busca constatar se o estagiário possui as habilidades para ensinar. Concepção esta que foi desenvolvida na primeira metade do século XX, vinculada ao campo da Didática, quando se tinha a ideia de se observar professores modelos ou escolas modelos. 
Na contemporaneidade, a ideia de professores modelos de escola deu lugar a uma prática de ensino nas escolas da comunidade. O papel do professor supervisor caminha na direção de orientar o estagiário na (re)descoberta da escola; levar o estagiário a vivenciar um processo de socialização, a entrar em contato com uma cultura escolar, a conhecer a proposta do Projeto Curricular Pedagógico e o planejamento de ensino da área, a entrar em contato com a realidade dos escolares e de seus saberes.

Dessa forma, no cenário da pesquisa foram encontrados dois contextos: o visível e o invisível. No contexto visível há, inicialmente, a compreensão de que à escola compete abrir as portas, segundo um dos diretores; e, para um dos professores supervisores, o seu trabalho se restringe a receber o estagiário, não sendo problema seu o acompanhamento desse estagiário. No que se refere ao professor orientador, a sua manifestação caminha na direção de que o ES precisa assumir uma configuração prescritiva, ressentindo-se de que os professores não entendem muito bem determinadas ações. A supervisora de ensino assume que ela, no começo, também não estava fazendo muita coisa, mas que, a partir dos problemas visualizados no campo do estágio, começou a se preocupar; enquanto a coordenadora da área de educação física, ao falar sobre o ES, comentou que não tinha noção.

A partir dessa compreensão, desvela-se outro contexto, muitas vezes invisível, em que diferentes participantes desta pesquisa revelam uma outra compreensão de como o ES pode ser organizado. A supervisora de ensino dá o primeiro passo para se pensar o ES como um tempo entre-dois, ao propor reuniões entre a Universidade e a Diretoria do Ensino, para organizar melhor os estágios na região. Um dos professores supervisores de ES de escola contesta as orientações do professor orientador, colocando que o estagiário precisa dar mais aulas e ficar menos na observação, o que é referendado pelo diretor de escola. A estagiária, por sua vez, ao ter o estágio com o referido supervisor, reconhece que com ele foi o melhor estágio que fez, questionando também a orientação do professor orientador ao restringir o ES a uma aula de regência, em que os estagiários são avaliados por ele com a relação à aula dada.

Nas entrelinhas das diferentes descrições apresentadas no corpo do texto, começa-se também a encontrar alguns dispositivos de formação: reunião entre Universidades e Diretoria de Ensino, ofício de apresentação do estagiário, projeto de ensino, acompanhamento do estagiário, observação de aulas, avaliação da aula de regência. Dessa forma, a primeira etapa da pesquisa termina com um diagnóstico de como alguns processos de formação se desenvolvem e apontam para uma perspectiva de reorganização do ES, que pode ocorrer se houver um trabalho de parceria mais orgânico a partir de um mapeamento a um grupo específico.

Os dados desse mapeamento específico abrem caminho para uma nova pesquisa em continuidade à primeira, mas, agora, avançando no sentido de constituição de uma rede de ensino não mais restrita à Educação Física, mas que a partir dela se amplia para todas as áreas de formação de professores. Optou-se por um trabalho construtivo-colaborativo, no sentido de que todos os parceiros (Universidade - Diretoria de Ensino - Escola) caminhem juntos em todas as decisões. Nesta nova etapa, quatro dispositivos vêm à tona: a reunião anual entre Diretoria de Ensino e Universidade para orientar na distribuição dos estagiários por escolas; a formação dos formadores em oficinas pedagógicas; o acolhimento como inserção do 
estagiário na escola; o encontro de estágio nas licenciaturas - momento em que os estagiários apresentam publicamente à comunidade os seus trabalhos. Paralelamente a isso, na organização desse trabalho se constituiu um GT - Formação na Diretoria de Ensino, em que todo mês há uma reunião para estudo ou planejamento das atividades de formação, envolvendo a Universidade e a Diretoria de Ensino.

No âmbito desse processo, caminha-se para a constituição de uma cultura profissional e de uma pedagogia da formação que entende que o ES ocupa um espaço próprio em que, muitas vezes, se encontra apenas o silêncio das universidades, das políticas educacionais e dos profissionais da área.

\section{Notas:}

1. Nóvoa (2019) utilizou como tempo entre-dois o fim da formação e o princípio da profissão, com ênfase para o início da carreira docente na forma de uma indução profissional. Porém, a indução profissional também pode ser compreendida como inserção profissional (Tardif, 2010). Neste contexto, nós consideramos o ES como a primeira etapa da inserção profissional.

2. Matérias Pedagógicas (Parecer CFE 292/1962; Resolução CFE 9/1969) - Psicologia da Educação (Adolescência e Aprendizagem), Didática, Estrutura e Funcionamento do Ensino, Prática de Ensino/Estágio Supervisionado (em escolas da comunidade, com 5\% de horas do total do curso) (Brasil, 1962, 1969).

3. Curso de Didática (Decreto-Lei 1190/39) - Didática Geral, Didática Especial, Psicologia Educacional, Administração Escolar, Fundamentos Biológicos da Educação e Fundamentos Sociológicos da Educação (Brasil, 1939).

4. Aprovado no comitê de ética sob o protocolo 7444.

\section{Referências}

ADRIÃO, T.; GARCIA, T.; BORGHI, R.; ARELARO, L. Uma modalidade peculiar de privatização da educação pública: a aquisição de "sistemas de ensino" por municípios paulistas. Educ. Soc., v. 30, n.108, p.799-818, oct. 2009.

ALTET, M. As competências do professor profissional: entre conhecimentos, esquemas de ação e adaptação, saber analisar. In: PAQUAI, Léopold; PERRENOU, Phillipe; ALTET, Marguerite; CHARLIER, Évelyne. Formando professores profissionais: que estratégias, quais competências. $2^{\mathrm{a}}$ ed. Porto Alegre: Artmed, 2001, p. 23-34.

ALTET, M. Profissionalização do ofício e da formação em questão: explorar as contribuições da pesquisa para fortalecer e refundar a prática da profissão. In: Spazzanni, M. L. Profissão de professor: Cenários, tensões e perspectivas. 1.ed. SP. Editora UNESP. 2016. 382p.

ALVEZ-MAZZOTTI, A; GEWANDSZNAJDER, F; O Método nas Ciências Naturais e Sociais: Pesquisa Qualitativa e Quantitativa. São Paulo: Pioneira Thomson Learning, 2001.

AZEVEDO, M. A. R. Os Saberes de Orientação dos Professores Formadores: Desafios para Ações Tutoriais Emancipatórias. Tese (Doutorado em Educação) - USP, São Paulo, 2009.

BATISTA, P; BORGES, C. Professor Cooperante: Papel e Desafios no Contexto Português e Quebequense. in: RESENDE, Rui; ALBUQUERQUE, Alberto; GOMES, Rui. Formação e Saberes em Desporto, 
Educação Física e Lazer. 1ed. Maia - PO: Edições ISMAI - Centro de Publicações do Instituto Superior da Maia, 2014, v. 1, p. 297-308.

BENITES, L.C. O professor-colaborador e o estágio curricular supervisionado em educação física: perfil, papel e potencialidades. Tese (Doutorado em Ciências da Motricidade). Instituto de Biociências, Universidade Estadual Paulista Júlio de Mesquita Filho, Rio Claro, 2012.

BORGES, C. A formação docente em Educação Física em Quebec: saberes espaços, culturas e agentes. In: XIV ENDIPE (livro 2 - anais): Trajetória e processos de ensinar e aprender: práticas e didáticas. Porto Alegre: EDIPUCRS, 2008

BRASIL. Ministério da Educação. Resolução CNE/CP n. 02/2019, de 20 de dezembro de 2019. Diário Oficial da União, Brasília, Seção 1, p. 115-119.

BRASIL. Ministério da Educação. Resolução CNE/CES 6/2018. Diário Oficial da União, Brasília, Seção 1, p. $48-49$.

BRASIL. Ministério da Educação. Resolução CNE/CP 02/2015. Diário Oficial da União, Brasília, Seção 1, n. 124, p. 8-12.

BRASIL. Ministério da Educação. Lei 11.788, 25/09/2008. Diário Oficial da União, Brasília.

BRASIL. Ministério da Educação. Resolução CNE/ CES 7, de 31 de abril de 2004. Brasília: Diário Oficial da União, Seção 1, p. 18-19.

BRASIL. Ministério da Educação. Resolução CNE/CP 1, de 18 de fevereiro de 2002. Diário Oficial da União, Brasília, 4 de março de 2002a. Seção 1, p. 8.

BRASIL. Ministério da Educação. Parecer CNE/CP 9, de 8 de maio de 2001, Brasília, n. 476, 2001.

BRASIL. Referencias para a formação de professores. Brasília: Ministério da Educação/ Secretaria de Educação Fundamental, 1999.

BRASIL. Ministério da Educação. Lei nº 9.394, de 20 de dezembro de 1996. Diário Oficial da União, Brasília, 23 dez. 1996.

BRASIL. Ministério da Educação. Lei nº 4.024, de 20 de dezembro de 1961. Diário Oficial da União, Brasília, 20 dez. 1961.

BRASIL. Conselho Federal de Educação. Decreto-lei no 1.190, de 4 de abril de 1939.

BRASIL Conselho Federal de Educação. Resolução n. 9, de 10 outubro de 1969 ».

CYRINO, M. Do acolhimento ao acompanhamento compartilhado: a construção colaborativa de uma proposta para o estágio curricular no curso de pedagogia. 2016. Tese (Doutorado em Educação) - UNESP, Rio Claro.

COCHRAN-SMITH, M. A tale oftwo teachers: learningtoteach over time. Kappa Delta Pi Record, vol. 48, n. 3, p. 108-122, 2012.

CONTRERAS, J. A autonomia de Professores. São Paulo: Cortez, 2002.

FARIA JUNIOR, A.G.; CORRÊA, E.S.; BRESSANE, R.S. Prática de ensino em educação física: estágio supervisionado. Rio de Janeiro: Interamericana, 1982.

FRANCO, M. A. S. Entre a lógica da formação e a lógica das práticas: a mediação dos saberes pedagógicos. Educação e Pesquisa, São Paulo. v. 34, n.7. p.109-126, jan./abr. 2008.

GATTI, B.; BARRETTO, E. S. Professores do Brasil: Impasses e desafios. Brasília: UNESCO, 2009.

GATTI, B. Formação de professores no Brasil: características e problemas. Educ. Soc., v. 31, n. 113, p. 13551379, out./dez. 2010

GATTI, B. A.; BARRETO, E. S. de S.; ANDRÉ, M. E. A; ALMEIDA, P. C. A. de. Professores do Brasil: novos cenários de formação. Brasília: UNESCO, 2019.

GIGLIO, C. M. B. Residência Pedagógica como diálogo permanente entre a formação inicial e continuada de 
professores. In: DALBEN, Ângela Imaculada Loureiro F. (et al). Convergências e tensões no campo da formação e do trabalho docente - Belo Horizonte: Autêntica, 2010.

GIL, A. C. Como elaborar projetos de pesquisa. 4. ed. São Paulo: Atlas, 2007.

HARGREAVES. A. Four Ages of Professionalism and Professional Learning. Teachers and Teaching: History and Practice,v. 6, n.2, p. 151-182, DOI: 10.1080/713698714 2000.

HOLMES GROUP. Tomorrow's teachers: A report of the Holmes Group. East Lansing. Michigan: Holmes Group, 1986.

HUBERMAN, M. O ciclo de vida profissional dos professores. In: NÓVOA, Antônio. (Org.). Vidas de professores. 2 ed. Portugal: Porto Editora, 1995. p. 31-61.

IMBÉRNÓN, F. Formação Docente e Profissional: Formar-se para a mudança e a incerteza. $9^{a}$ edição. São Paulo: Cortez, 2011.

ISSE, S. F.; MOLINA NETO, V. Estágio supervisionado na formação de professores de Educação Física: produções científicas sobre o tema. J. Phys. Educ. v. 27, p. 1-16, e2759, 2016.

JOVCHELOVITCH, S; BAUER, M. W. Entrevista Narrativa. In: JOVCHELOVITCH, S; BAUER, M. W. Pesquisa qualitativa com texto, imagem e som: um manual prático. Tradução de Pedrinho A. Guareschi. 8. ed. Petrópolis: Vozes, 2002.

KULCSAR, R. O Estágio supervisionado como atividade integradora. In: Piconez, S. C. B. (Coord.) A Prática de Ensino e o estágio supervisionado. $3^{a}$ ed. Campinas: Papirus,1998, p. 63-74.

LIBÂNEO, J.C.; PIMENTA, S. Formação de profissionais da educação: Visão crítica e perspectiva de mudança. Educação \& Sociedade, v. 20, n. 68, p. 239-277, dez. 1999

LUDKE, M; ANDRÉ, M. E. D. A. Pesquisa em Educação: Abordagens qualitativas. 6a reimpressão. São Paulo: EPU, 2001.

MARCELO GARCIA, C. Formação de professores - para uma mudança educativa. Porto: Porto Editora. 1999.

MOREIRA, S. V. Análise documental como método e como técnica. In: DUARTE, Jorge; BARROS, A. (Org.). Métodos e técnicas de pesquisa em comunicação. São Paulo: Atlas, 2005. p. 269-279.

NÓVOA, A. Entre a formação e a profissão: ensaio sobre o modo como nos tornamos professores. Currículo sem Fronteiras, v. 19, n. 1, p. 198-208, jan./abr. 2019.

NÓVOA, A. Firmar a posição como professor, afirmar a profissão docente. Cadernos de Pesquisa, v. 47, n. 166, p. 1106-1133, out./dez., 2017.

NÓVOA, A. Formação de professores e formação docente. In: NÓVOA, Antônio (org.). Os Professores e sua Formação. Lisboa: Nova Enciclopédia, 1992.

OLIVEIRA, A. A. P. Análise documental do processo de capacitação dos multiplicadores do projeto "Nossas crianças: Janelas de oportunidades" no município de São Paulo à luz da Promoção da Saúde. 210 f. Dissertação (Mestrado em Enfermagem em Saúde Coletiva) - Escola de Enfermagem, Universidade de São Paulo, São Paulo, 2007

OLIVEIRA, D. As políticas de formação e a crise da profissionalização docente: por onde passa a valorização. Revista Educação em Questão, v. 46, n. 32, p. 51-74, maio/ago. 2013

OLIVEIRA, D.; SANTOS, K. A. Políticas de formação docente e a educação em tempo integral. Revista Práxis Educacional, v. 14, n. 28, p. 16-40, abr./jun. 2018.

RIBEIRO, L. T. F.; ARAUJO, O. H. A. O estágio supervisionado: fios, desafios, movimentos e possibilidades de formação. RIAEE - Revista Ibero-Americana de Estudos em Educação, v. 12, n3., p. 1721-1735, jul./set. 2017.

RINALDI, R. P.; DAL-FORNO, J. P.; REALI, A. M. M. R. Programa de desenvolvimento profissional online 
para formadores em início de carreira na educação básica. Anais da 32a . Reunião da ANPED. 2009. Disponível em: <http://www.anped.org.br/reunioes/32ra/arquivos/trabalhos/GT16-5708--Int.pdf>. Acesso em: 25 de março de 2013

SÃO PAUlO (CREF-4). Guia de Normas e Procedimentos da Boa Prática da Educação Física e Esporte na Escola. São Paulo: CREF-4, 2013.

SARTI, F.M Dimensão socioprofissional da formação docente: aportes teóricos e proposições. Cadernos de Pesquisa, v. 50, n. 175, p. 294-315, jan./mar. 2020.

SARTI, F. M. Pelos caminhos da universitarização: reflexões a partir da masterização dos IUFM franceses. Educação em Revista, v. 29, p. 215-244, 2013

SARTI, F. M. Parceria Intergeracional e Formação Docente. Educação em Revista, v, 25, n.02, p. 133-152, ago. 2009.

SAVIANI, D. Desafios da construção de um sistema nacional articulado de educação. Trabalho, Educação e Saúde, v.6, n. 2, p. 213-231, jul./out., 2008.

SAVIANI, D. Formação de professores: aspectos históricos e teóricos do problema no contexto brasileiro. Revista Brasileira de Educação, v. 14, n. 40, p.143-155, jan./abr., 2009.

SAVOIE, P. Aux origines de la professionnalisation? La genèse du corps enseignant secondaire français. Education\&Sociétés, n. 23, v. 1, p. 5-13, 2009.

SILVA JÚNIOR, A.P; OLIVEIRA, A.A.B. Estágio curricular supervisionado na formação de professores de educação física no Brasil: uma revisão sistemática. Movimento, v. 24, n. 1., p. 77-92, jan./mar. 2018.

SOUZA NETO, S.; BENITES, L. Os desafios da prática na formação inicial docente: experiência da educação física da UNESP de Rio Claro. Cadernos de Educação, n. 46, p. 02-22, set./dez., 2013. https://doi.org/10.15210/CADUC.V0I46.417

SOUZA NETO, S; SARTI, F. M.; BENITES, L. C. Entre o ofício de aluno e o habitus de professor: os desafios do estágio supervisionado no processo de iniciação à docência. Movimento, Porto Alegre, v. 22, n. 1, 311324, jan./mar. de 2016. https://doi.org/10.22456/1982-8918.49700

SOUZA NETO, S.; CYRINO, M.; BORGES, C. O Estágio Curricular Supervisionado como Lócus Central da Profissionalização do Ensino. Revista Portuguesa de Educação, v. 32, n. 1, p. 52-72, 2019. doi: 10.21814/rpe.13439

TARDIF, M.; RAYMOND, D. Saberes, tempo e aprendizagem do trabalho no magistério. Educação \& Sociedade. Ano XXI, n. 73, p. 209-244, dez./2002.

TARDIF, M. Saberes Docentes e Formação Profissional. 10a Edição. Petrópolis: Vozes, 2010.

TARDIF, M. A profissionalização do ensino passados trinta anos: dois passos para a frente, três para trás. Educação \& Sociedade, v. 34, n. 123, p. 551-571, 2013.

THIOLLENT, M. Metodologia da pesquisa-ação. São Paulo: Cortez, 1994.

VALLE, I.R. A era da profissionalização: formação e socialização profissional do corpo docente de 1a. a 4a. série. Florianópolis: Cidade Futura, 2003

VEDOVATTO, D.; SOUZA NETO, S. Os desafios do estágio curricular supervisionado em educação física na parceria entre Universidade e Escola. Movimento, v. 21, n. 1, p. 111-124, jan./mar., 2015ahttps://doi.org/10.22456/1982-8918.46271

VEDOVATTO, D.; SOUZA NETO, S. Por uma revolução na prática de ensino: o estágio curricular supervisionado. $1^{\mathrm{a}}$ edição, Curitiba, CRV, 2015b 


\section{Correspondência}

Dijnane Vedovatto: Professora do Departamento de Metodologia de Ensino da Universidade Federal de São Carlos - UFSCar/São Carlos. Docente do Programa de Pós-Graduação em Educação (PPGE - UFSCar) e do Programa de Pós-Graduação Profissional em Educação (PPGPE - UFSCar). Atua na coordenação do grupo de estudos Docência, Estágio Supervisionado e Formação de Professores em Educação Física (DEFEF/UFSCar/São Carlos), e Coordenação em parceria do Núcleo de Estudos e Pesquisas em Educação Física: Formação Profissional no Campo de Trabalho - UNESP/Rio Claro (NEPEF/UNESP/Rio Claro). Pesquisadora internacional do Centre international de recherche sur la formation et la profession d'enseignants - CRIFPE. Membro da Association Francophone pour le Savoir (ACFAS). Membro do Centre de la francophonie des Amériques. Membro da Antena CRIFPE-Brasil (Centre international de recherche sur la formation et la profession d'enseignants - Brasil.

E-mail: dijnane@ufscar.br

Orcid: https://orcid.org/0000-0002-7435-6849

Samuel de Souza Neto: Professor do Departamento de Educação da Universidade Estadual Paulista (UNESP/campus de Rio Claro), do qual foi chefe. Na UNESP/RC foi coordenador do Núcleo de Ensino, membro do Conselho de Pós-Graduação em Educação, coordenador dos Cursos de Graduação em Educação Física e Coordenador do Programa de Pós-Graduação em Ciências da Motricidade. Recebe bolsa de Produtividade em Pesquisa - Educação (Conselho Nacional de Desenvolvimento Científico e Tecnológico - CNPq,desde 2010). Atua na coordenação em parceria do Núcleo de Estudos e Pesquisas em Educação Física: Formação Profissional no Campo de Trabalho - UNESP/Rio Claro (NEPEF/UNESP/RC) e na coordenação em parceria do Grupo de Pesquisa Docência, Formação de Professores e Práticas de Ensino (DOFPPEN/UNESP/RC). É membro do Grupo de Trabalho 8 Formação de Professores - ANPED, Grupo de Trabalho Formação Profissional e Mundo do Trabalho COMBRACE; Association Francophone pour le Savoir (ACFAS); Centre de la francophonie des Amériques; pesquisador internacional do CRIFPE (Centre interuniversitaire de recherche sur la formation et La profession d'enseignants) e diretor do Centre international de recherche sur la formation et la profession d' enseignants - Brasil (CRIFPE - Brasil). A sua investigação focaliza a formação de professores e o trabalho docente, com ênfase para a docência como profissão e os processos de profissionalização; o estágio supervisionado e a análise da prática; e, as políticas públicas de formação.

E-mail: samuel.souza-neto@unesp.br

Orcid: https://orcid.org/0000-0002-8991-7039

Texto publicado em Currículo sem Fronteiras com autorização dos autores. 